\title{
France toughens conflict rules
}

\section{Law demands greater transparency for health experts.}

\section{BY DECLAN BUTLER}

$\mathrm{A}$ draconian new law aims to toughen France's relaxed approach to conflicts of interest for scientists who advise the government on pharmaceuticals. Approved last week by the French National Assembly, the law is intended to restore public confidence in the country's embattled drug regulatory system. It mandates fines of up to $€ 30,000$ (US\$40,000) for advisers who fail to declare all their competing interests.

The law, which is yet to be voted on by the French Senate, is a response to the 'Mediator scandal', in which the French authorities are alleged to have acted too slowly when they withdrew the diabetes drug Mediator (benfluorex) from the market in November 2009. Press reports have suggested that advisers' ties to the pharmaceutical industry may have contributed to a tardy response to long-standing concerns about potentially fatal cardiac side effects. Some scientists argue, however, that the Mediator affair has been blown out of proportion by the media, and that the facts of the case including what, if any, role conflicts of interest had - will become clear only with the conclusions of an ongoing judicial investigation.

Given the outcry, it is reasonable for the government to try to rebuild public trust in the drug regulatory system, says Claude Le Pen, a health economist at Paris-Dauphine University. But he and other experts argue that the law is largely a short-term, populist response that fails to address more fundamental weaknesses in the regulatory system. "The law's aim is more political, more a public-communication exercise, than a reform of the system," he says.

The national drug regulator, AFSSAPS, and many other French health bodies have long had policies requiring experts to declare any interests that might raise questions about impartiality, such as being a paid consultant for a particular drug company. But these have not been well enforced and are often ignored.

The new law brings in a harmonized national system for handling experts' competing interests throughout the health system, and gives it penal teeth, says Marc Rodwin, an expert in comparative health law at Suffolk University Law School in Boston, Massachusetts.

Under the law, external experts and in-house staff within the health system would have to declare all competing interests. Companies would also be obliged to maintain a public register of all agreements with, and payments to, anyone involved in health care. This provision, which experts believe is far more sweeping than in other countries, goes beyond expert advisers,

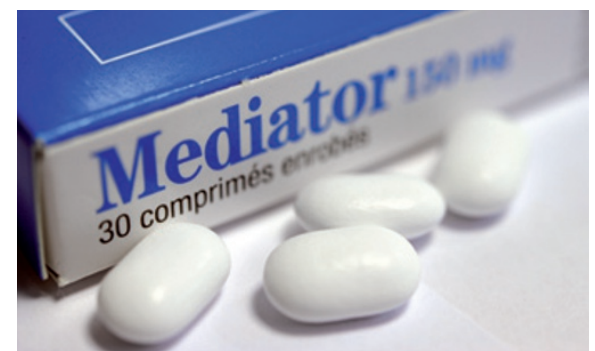

Some believe that conflicts of interest may have slowed the decision to withdraw Mediator.

and applies to all medical professionals, associations, charities, institutions and students, as well as the trade press and learned societies.

Minutes from committee meetings within the regulatory system would in future be publicly available, with the exception of discussions involving confidential personal-health or commercial information. The law would also dissolve AFSSAPS and replace it with a National Agency for Medicine Safety, although whether this will be any more than a symbolic change is unclear.

But the law fails to address the regulatory agencies' heavy reliance on external academic experts, many of whom inevitably have ties with industry. Rodwin argues that the agencies have neglected to build up a sufficient corps of in-house experts, as the US Food and Drug Administration and many other regulatory agencies have done. Le Pen adds that the new law's sanctions could discourage researchers from serving on government advisory committees - generally an unpaid role.

In most countries, ties with industry are widely accepted, and transparency is seen as the best way to deal with potential conflicts. In France, however, honest scientists who declare competing interests are often not seen by the public as transparent; rather, they are frequently vilified in the French media and Internet forums as lackeys of industry, Le Pen says.

That attitude is deeply rooted in the French psyche. In contrast to the United States or Germany, people in France - paradoxically, another leading capitalist economy - tend to be suspicious of profit, entrepreneurship and industry, says Francis Megerlin, an expert in comparative law at the University of ParisDescartes, currently at the Berkeley Center for Health Technology in Oakland, California.

The real issue, he says, is that the government is trying to put in place legislation loosely modelled on that set out in the US Physician Payments Sunshine Act of 2009, which requires drug companies to disclose payments made to physicians. "The problem is that on the sociological and ideological level the context is completely different," says Megerlin. Scientists say they see no easy solution to the dilemma.

The law is being pushed through the legislature using the 'accelerated procedure', which means that it requires only one reading in the parliament and the Senate, instead of the usual two. The text will come before the Senate on 26 October, but observers expect it to fly through with few significant changes.

\section{CORRECTION}

The Editorial 'Heritage threats' (Nature $\mathbf{4 7 7}, 510 ; 2011$ ) originally stated that Ireland was leading the European Joint Programming Initiative. In fact, Italy has overall responsibility for coordination.

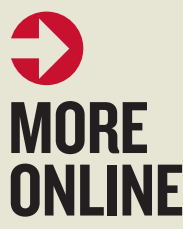

\section{TOP STORY}

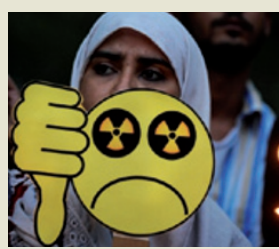

Safety fears put India's nuclear future on hold go.nature.com/ aabrim

\section{MORE NEWS}

- MERMAIDs detect distant earthquakes go.nature.com/lusaby - HIV risk of progesterone contraceptives was long suspected go.nature.com/cwmy5n - Faster-than-light neutrinos face time trial go.nature.com/lcopv7

\section{PODCAST}

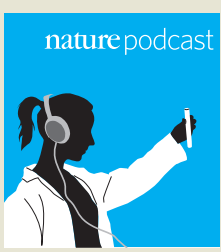

Editor Henry Gee talks about Futures, Nature's long-running science-fiction column go.nature. com/bozkn5 